\title{
MENUJU ERA GLOBALISASI PENDIDIKAN: Tantangan dan Harapan bagi Perguruan Tinggi di Tanah Air
}

\author{
Moh. Wayong \\ Fakultas Tarbiyah dan Keguruan \\ Universitas Islam Negeri Alauddin Makassar \\ J1. H. M. Yasin Limpo No. 36 Samata, Gowa
}

\begin{abstract}
The global insight is a perspective arising from the awareness that in this life everything is always related to the wider world, the global world. Every college in the homeland is no longer possible to isolate themselves from global influence. Universities in the country have been part of the world movement, so that each institution needs to pay attention to the interests of fellow institutions. Every practice in college needs to avoid narrow mindedness, compartmentalized by subjective, primordial and thinking with a pragmatic approach.
\end{abstract}

Keywords: Education Globalization, Global Insights, Expectations and Challenges

\section{PENDAHULUAN}

7 he Center of the National Research Scientific (CNRS), Prancis, mengklaim bahwa dunia dewasa ini sedang masuki babak baru perkembangan globalisasi, yaitu globalisasi budaya. Kronologis globalisasi menunjukkan bahwa hingga saat ini sudah ada tiga tahap globalisasi. Globalisasi pertama adalah globalisasi politik yang dimulai dengan terbentuknya Persatuan Bangsa- Bangsa (PBB) pada tahun 1945. Tiga puluh tahun setelah globalisasi politik, sekitar pertengahan tahun 1970an, muncul globalisasi ke dua yaitu globalisasi ekonomi yang ditandai dengan lahirnya perdagangan bebas serta terbentuknya kerjasama ekonomi level internasional dan regional seperti APEC dan AFTA. Kemudian tiga puluh tahun berikutnya lagi, sekitar pertengahan tahun 2000an, dunia ini memasuki globalisasi ke tiga, yaitu globalisasi budaya. Ciricirinya adalah bangsa-bangsa di dunia menuju kepada satu kultur besar untuk di sharing bersama-sam, serta semakin memudarnya identitas budaya lokal tertentu (Kompas edisi 14, November 2004). Dari kronologis tersebut, dapat diprediksi bahwa 30 tahun dari pertengahan tahun 2000an, yaitu tahun 2035, akan muncul era baru globalisasi, kemungkinan besar globalisasi pendidikan.

Hingga tahap ini, globalisasi budaya merupakan yang paling rumit. Kerumitan globalisasi budaya disebabkan begitu banyaknya keanekaragaman di dunia. Di satu sisi ada ambiguitas yang melekat pada globalisasi ini yaitu sangat terbukanya dunia. Namun di sisi lain ada daya dan kecenderungan untuk mempertahankan nilai budaya tertentu, karena globalisasi budaya mendorong upaya untuk mengetahui perbedaan satu sama lain. Pergeseran budaya yang kian sering terjadi diduga akan mengakibatkan 
penguatan budaya-budaya lokal karena setiap bangsa ingin mempertahankan identitas budaya tersendiri. Namun demikian, pemahaman terhadap proses ini bisa menstabilkan situasi budaya dunia yang mengalami kegoncangan saat berlangsungnya globalisasi politik dan, terutama, globalisasi ekonomi yang telah membuat jurang yang dalam antara negara-negara utara dan selatan atau negara-negara maju dan sedang berkebang.

Faktor yang mempengaruhi terjadinya globalisasi generasi ketiga ini adalah kecepatan informasi dan intensitas komunikasi yang semakin tinggi. Dengan kecepatan informasi dan komunikasi, globalisasi politik dan ekonomi hanya bisa membuat dekatnya jarak territorial. Sedangkan globalisasi budaya memperlihatkan hal yang lebih dari itu, yaitu upaya mengetahui perbedaan satu sama lain. Globalisasi akan membuat setiap orang mengetahui apapun yang terjadi pada waktu seketika di dunia ini melalui media komunikasi yang serba canggih. Globalisasi dapat juga membuat manusia berkompetisi secara terbuka karena kedekatan waktu dan jarak, seperti kebanyakan kalangan ilmuan menyebutkan the world is a small village.

Hingga kini, secara terminologis, istilah globalisasi pendidikan belum populer di masyarakat karena globalisasi pendidikan memang belum terjadi, dan globalisasi itu sendiri merujuk pada seluruh aspek kehidupan manusia, bukan hanya pada satu aspek saja. Aspek tersebut saling berhubungan satu sama lain dan tidak mengenal batas-batas geografis negara, ataupun ikatan primordial seperti suku, ras dan agama. Jika merujuk pada pengertian globalisasi seperti itu maka globalisasi pendidikan dapat dirumuskan sebagai praktek penyelenggaraan pendidikan, pengajaran dan pelatihan yang tidak mengenal batas geografis negara. Dengan wawasan seperti ini maka lembaga pendidikan asing dapat mendirikan institusi dan menyelenggarakan berbagai kegiatan dan program pendidikan di negara-negara lain, dan begitu pula sebaliknya. Inilah yang menjadi salah satu permasalahan fundamental penyelenggaraan pendidikan di tanah air dewasa ini dan pada masa yang akan datang.

Tulisan ini didesain untuk mengkaji berbagai permasalahan pendidikan di tanah air yang berkaitan dengan globalisasi. Termasuk dalam kajian ini adalah analisis berbagai praktek dan wawasan pendidikan di tanah air yang dapat menjadi embrio lahirnya globalisasi pendidikan. Tulisan ini juga akan membahas berbagai langkah lembaga pendidikan dalam menghadapi pengaruh globalisasi agar globalisasi tersebut dapat diterima secara konstruktif. Pembahasan tentang globalisasi pendidikan dalam tulisan ini akan diawali dengan pemaparan pandangan-pandangan mengenai apa sesungguhnya globalisasi tersebut.

\section{PEMBAHASAN}

\section{A. Sekilas Tentang Globalisasi}

Kata globalisasi berasal dari kata bahasa Inggris global yang berarti universal. Dari kata global menjadi globalization yang bisa dimaknai sebagai proses universalisasi. Jadi globalisasi bisa diartikan sebagai proses penyebaran unsur-unsur 
baru pada seluruh aspek kehidupan manusia, termasuk aspek informasi, teknologi, kesehatan, perdagangan, pendidikan, pemikiran, gaya hidup, dan lain-lain secara mendunia. Pemaknaan lain dari globalisasi adalah proses dimana pengalaman kehidupan sehari-hari, ide-ide dan informasi menjadi standar di seluruh dunia, karena apapun yang ditemukan atau terjadi di bagain manapun di dunia ini akan menyebar ke belahan dunia lainnya dengan mudah dan sangat cepat.

Thomas Larsson (2001) dalam buku "The Race to the Top: The Real Story of Globalization" mengemukakan bahwa globalisasi merupakan proses penyusutan dunia sehingga jarak semakin pendek dan segala hal terasa semakin dekat. Globalisasi mengacu pada semakin mudahnya interaksi antara seseorang di satu tempat dengan orang lain di belahan dunia yang lain karena kemajuan sains dan teknologi terutama pada bidang komunikasi. Batas negara seakan-akan telah tiada lagi. Seseorang dapat melintasi beberapa negara hanya dalam waktu beberapa jam saja. Batas waktu juga seolah-olah tidak ada lagi. Berkomunikasi dengan tetangga yang jaraknya hanya 10 meter di sebelah rumah sama mudahnya dengan berkomunikasi dengan kerabat di negara atau di benua lain.

Sejalan dengan Larsson, Anthony Giddens (1991: 64) memaknai globalisasi sebagai intensifikasi hubungan sosial dunia yang menghubungkan tempat-tempat jauh sehingga peristiwa di suatu tempat dapat dipengaruhi oleh peristiwa yang terjadi di tempat lain. Kondisi ekonomi yang membaik pada satu negara atau kawasan akan mempengaruhi perbaikan ekonomi pada negara atau kawasan lainnya. Sebaliknya, jika terjadi krisis ekonomi pada satu kawasan akan mengancam kondisi kondisi ekonomi pada kawasan lain. Sama halnya penyakit yang beberapa tahun terakhir ini mewabah di Korea, China dan Arab Saudi mengancam kondisi kesehatan masyarakat dunia lainnya tanpa mengenal jarak.

Jika globalisasi dimaknai dengan proses penyusutan dunia yang membuat jarak semakin dekat serta hilangnya batas waktu, maka pada hakekatnya globalisasi adalah kompetisi. Ketika Arab Saudi, Korea Selatan dan Jepang terasa dekat maka bangsa Indonesia memiliki potensi untuk bersaing di negara tersebut untuk berbagai kegiatan, termasuk pendidikan dan pekerjaan, dan begitu pula sebaliknya. Fakta menunjukkan bahwa banyak bangsa Indonesia yang sedang belajar dan menjadi tenaga kerja di negara tersebut, terutama di Arab Saudi. Terlepas dari status pekerjaan mereka, faktor globalisasi telah membuat para tenaga kerja Indonesia (TKI) dari berbagai pelosok tanah air yang sebagian besar dengan bekal pendidikan yang sangat minim mampu melintasi beberapa negara untuk sebuah pekerjaa, termasuk menjadi pembantu rumah tangga.

Selanjutnya, jika hakekat dari kompetisi adalah keunggulan maka dalam konteks ini akan berlaku teori Darwin "the survival of the fittest". Dengan teori ini akan muncul seleksi alam bahwa pihak yang unggullah yang akan bertahan. Pada sektor pendidikan di tanah air, lembaga pendidikan swasta baik tingkat SLTP, SLTA maupun perguruan 
tinggi menjamur di tanah air terutama tahun 1980an. Menjamurnya pendirian lembaga pendidikan swasta tersebut dipicu oleh membludaknya jumlah calon siswa dan mahasiswa baru yang tidak tertampung pada instutusi pendidikan negeri. Dengan kebijakan pemerintahan ORDE BARU sejak tahun 1972 untuk mengendalikan angka kelahiran dengan slogan "dua anak cukup, laki-laki perempuan sama saja" membuat calon siswa dan mahasiswa baru menurun secara drastis mulai tahun 1990an. Akibatnya, seleksi alam berlaku sehingga banyak lembaga pendidikan swasta yang bangkrut, tutup, dan hanya pihak yang unggullah yang tetap bertahan.

Pada tingkat Internasional, contoh menarik dengan teori Darwin ini adalah Singapura. Di negara ini boleh dikatan bahwa tidak ada perkebunan karet disana, namun negara inilah yang menjadi pengekspor karet nomor 1 di dunia. Indonesia dan Malaysia bukan pengekspor karet ternama walaupun kenyataannya kedua negara inilah yang menjadi sumber bahan baku tersebut terbesar di dunia. Keunggulan negara Singapura adalah faktor kualitas pengemasan bahan baku yang dinilai lebih memenuhi standar Eropa dan Amerika sebagai tujuan ekspor komoditi tersebut. Sama halnya dengan buah kaleng, ketika Singapura, Malaysia, Indonesia serta beberapa negara ASEAN lainnya masing-masing mengolah produk tersebut dengan standar mereka masing-masing, lalu mempromosikan ke pasar dunia. Dari sisi mutu pengolahan, Singapura selalu lebih unggul dan menyingkirkan produk negara-negara lain. Inilah yang dimaksud teori Darwin bahwa hakekat dari globalisasi adalah keunggulan, yaitu pada era globalisasi akan terjadi seleksi alam yaitu hanya pihak unggul yang dapat bertahan.

Dari beberapa contoh tersebut di atas dapat ditegaskan bahwa Globalisasi, merupakan suatu interdependensi yang tidak simetris antarnegara, lembaga, dan bahkan antar aktornya. Interdependesi antar negara pada era globalisasi lebih menguntungkan negara yang memiliki keunggulan ekonomi dan teknologi, karena globalisasi mendorong persaingan bebas secara internasional. Padahal, globalisasi awalnya bertujuan untuk memberi peluang bagi negara-negara berkembang untuk meningkatkan kesejahteraannya melalui perdagangan global. Globalisasi yang dimotori fundamentalisme pasar yang dalam manifestasinya mengambil bentuk pasar bebas dengan berbagai isntrumennya sangat merugikan negara-negara berkembang yang masih lemah ekonomi dan teknologinya. Namun demikian, justru globalisasi seperti itulah yang dipaksakan kepada negara-negara berkembang.

\section{B. Globalisasi dan Internasionalisasi}

Globalisasi dan internasionalisasi adalah dua kata yang maknanya berbeda namun mirip dan memiliki keterkaitan yang sangat erat. Dalam banyak hal, globalisasi mempunyai banyak karakteristik yang sama dengan internasionalisasi sehingga kedua istilah ini sering dipertukarkan. Berikut ini beberapa situasi yang menandakan semakin berkembangnya fenomena globalisasi di dunia:

- Terjadinya perubahan dalam konteks ruang dan waktu. Perkembangan barangbarang seperti telepon genggam, televisi satelit, dan internet menunjukkan bahwa 
komunikasi global terjadi demikian cepatnya, sementara melalui pergerakan massa semacam turisme memungkinkan kita merasakan banyak hal dari budaya yang berbeda.

- Pasar dan produksi ekonomi di negara-negara yang berbeda menjadi saling bergantung sebagai akibat dari pertumbuhan perdagangan internasional, peningkatan pengaruh perusahaan multinasional, dan dominasi organisasi semacam World Trade Organization (WTO).

- Peningkatan interaksi kultural melalui perkembangan media massa (terutama televisi, film, musik, dan transmisi berita dan olah raga internasional). Saat ini, kita dapat mengonsumsi dan mengalami gagasan dan pengalaman baru mengenai halhal yang melintasi beraneka ragam budaya, misalnya dalam bidang fashion, literatur, dan makanan.

- Meningkatnya masalah bersama, misalnya pada bidang lingkungan hidup, krisis multinasional, inflasi regional dan lain-lain (Scholte, 2001)

Transformasi seperti yang terungkap diatas telah membawa bangsa-bangsa di dunia ini pada globalisme, sebuah kesadaran dan pemahaman baru bahwa dunia adalah satu. Bangsa-bangsa di dunia ini sadar bahwa sebenarnya telah turut ambil bagian dalam sebuah dunia yang harus berubah tanpa terkendali yang ditandai dengan selera dan rasa ketertarikan akan hal sama, perubahan dan ketidakpastian, serta kenyataan yang mungkin terjadi, dan inilah yang disebut sebagai zaman transformasi sosial.

Globalisasi kini menjadi suatu hal yang amat penting dalam hubungan internasional. Globalisasi telah mempengaruhi berbagai aspek dalam hubungan internasional, mulai dari ekonomi hingga budaya. Dalam tiga dekade terkahir skala dan lingkup keterlibatan global semakin jelas. Keberadaan globalisasi semakin tampak nyata. Dengan globalisasi yang semakin deras, batas negara seolah-olah bukan merupakan suatu hambatan dalam tercapainya hubungan internasional. Perdagangan bebas semakin marak, bahkan seorang individu dapat melakukan hubungan secara mudah dengan individu negara lain melalui internet.

Sejalan dengan globalisasi, internasionalisasi pada dasarnya dapat dipandang sebagai proses meningkatnya hubungan internasional, dimana diantara negara tergantung satu sama lain dan menciptakan hubungan yang intens untuk memenuhi kebutuhan masing-masing. Dalam dunia pendidikan, khususnya pendidikan tinggi, sejak awal kelahirannya telah berkenalan baik dengan internasionalisasi, bahkan dapat dikatakan bahwa pendidikan tinggi adalah buah dari internasionalisasi ilmu pengetahuan, seni, dan budaya. Karena menyadari manfaat besar dan positif dari internasionalisasi, hampir tidak ada negara yang secara sadar mau memisahkan dirinya dari arus internasionalisasi. Dalam Pembukaan UUD 1945, bahkan tercantum jelas bahwa salah satu tujuan pendirian Republik Indonesia sangat dijiawai semangat internasionalisme, yairu "...ikut melaksanakan ketertiban dunia yang berdasarkan kemerdekaan, perdamaian abadi, dan keadilan social..." 
Internasionalisasi mulanya adalah hasil evolusi dari globalisasi dibidang politik, ekonomi dan perdagangan, serta budaya. Era globalisasi merupakan istilah di mana dunia tidak lagi mengenal batas serta akselerasi hegemoni kultur yang dapat menyebabkan potensi terjadinya suatu fenomamena global dimana suatu tindakan yang dilakukan oleh negara-negara di suatu bagian negara akan berpengaruh bagi negara lain. Globalisasi yang terjadi secara tiba-tiba menciptakan suatu krisis multidimensi yang menimpa suatu bangsa ketika bangsa tersebut tidak siap. Sebaliknya, kesiapan bangsa menghadapi globalisasi akan berevolusi menjadi tahapan internasionalisasi dimana unsur-unsur bidang politik lebih dominan daripada ekonomi dan budaya, dan internasionalisasi tersebut dijadikan salah satu strategi menghadapi kompetisi global yang terjadi.

Untuk memaksimalkan relasi internasional tersebut berkembanglah liberalisasi yaitu menurunnya batas-batas antar Negara seperti yang terlihat pada ASEAN Free Trade Area (AFTA), dimana tercipta interaksi perdagangan yang lebih bebas diantara anggotanya, tidak lagi terikat oleh batas negara. Secara umum, liberalisme mencitacitakan suatu masyarakat yang bebas, dicirikan oleh kebebasan berpikir bagi para individu. Paham liberalisme menolak adanya pembatasan, khususnya dari pemerintah dan agama. Liberalisme menghendaki adanya, pertukaran gagasan yang bebas, ekonomi pasar yang mendukung usaha pribadi yang relatif bebas, dan suatu sistem pemerintahan yang transparan, dan menolak adanya pembatasan terhadap pemilikan individu. Paham liberalisme lebih lanjut menjadi dasar bagi tumbuhnya kapitalisme. Dalam masyarakat modern, liberalisme akan dapat tumbuh dalam sistem demokrasi, hal ini dikarenakan keduanya sama-sama mendasarkan kebebasan mayoritas. Kebebasan adalah tujuan tersendiri bagi liberalis. Tanpa kebebasan manusia tidak dapat berkembang dan masyarakat tidak dapat berfungsi. Oleh karena itu gagasan kebebaan di setiap masa dan tempat selalu memainkan peran dalam masyarakat.

Internasionalisasi pada segi sosial budaya mempunyai dampak terhadap terbentuknya global society, dimana masyarakat dunia sudah menjadi satu masyarakat global. Semangat kebersamaan kini tidak hanya hadir pada lingkup nasional namun berkembang secara global dengan ikatan yang lebih universal. Sebenarnya dalam dunia global ada saling pengaruh budaya dari Barat ke Timur atau sebaliknya dari Timur ke Barat. Namun budaya global ini akan dikuasai oleh negara pencipta teknologi informasi. Kemajuan sains dan teknologi berada pada pihak Barat sehingga negara-negara yang lemah pada bidang teknologi informasi akan cenderung terpengaruh oleh budaya Barat. Salah satu contohnya adalah pada seni musik. Lagu-lagu barat seolah menjadi kiblat dan patokan bagi seluruh industri musik di dunia. Hal ini membuat budaya barat akan lebih mudah go internasional, memberikan pengaruh terhadap budaya lain di seluruh dunia pada sektor ini. Faktor inilah yang membuat sebagian orang rancu antara globalisasi dengan westernisasi, pada hal westernisasi hanyalah salah satu bentuk internasionalisasi 
dengan semakin menyebarnya pikiran dan budaya dari barat karena adanya dukungan dari kemajuan eknologi informasi.

Internasionalisasi pada sektor pendidikan merupakan satu hal yang tidak dapat dihindari. Dewasa ini pendidikan merupakan tolak ukur amat penting oleh masyarakat dunia untuk melihat maju tidaknya sebuah bangsa. Negara-negara maju sibuk membangun sebuah system pendidikan yang mendukung dan dianggap bisa mencakup sebuah system yang tidak hanya bisa diakses oleh masyarakatnya akan tetapi bangsa lain juga bisa menimba ilmu dari Negara tersebut. Inovasi sistem pendidikan dimaksudkan untuk mencapai target agar negara tersebut bisa dilirik atau bahkan menjadi contoh dan panduan untuk negara lain bahwa negara tersebut memiliki system pendidikan yang mumpuni dan mampu memenuhi kuota internasional. Kecenderungan dalam dunia pendidikan semacam ini dapat dianggap sebagai embrio lahirnya globalisasi pendidikan.

\section{Globalisasi Pendidikan Tahun 2035?}

Istilah internasionalisasi pendidikan sering disepadankan dengan globalisasi pendidikan walau maknanya berbeda. Internasionalisasi pendidikan mengandung arti bahwa penyelenggaraan pendidikan dilaksanakan dengan menembus batas negara melalui jaringan kerjasama, pembukaan cabang lembaga pendidikan oleh sebuah negara di negara-negara lain (di luar negeri) atau pembukaan akses siswa/mahasiswa domestik ke lembaga pendidikan internasional. Proses internasionalisasi pendidikan seperti ini tercipta karena dipicu oleh arus globalisasi dan karena kepentingan politik. Sedangkan globalisasi pendidikan merupakan sebuah proses yang mengandung arti bahwa penyelenggaraan pendidikan dilaksanakan dengan menembus batas negara melalui jaringan kerjasama, pembukaan cabang lembaga pendidikan oleh sebuah negara di negara-negara lain karena kemajuan teknologi informasi dan komunikasi. Proses hubungan dan interaksi yang terjadi dalam konteks globalisasi jauh lebih kompleks karena melibatkan banyak kekuatan di dalamnya yaitu antar negara, pasar global dan individu atau kelompok, sedangkan internasionalisasi pendidikan hanya dalam bentuk hubungan antar negara (government to government).

Harian Kompas edisi 14, november 2004 memuat kronologis globalisasi yang pernah terjadi. Globalisasi pertama adalah globalisasi politik yang ditandai dengan lahirnya Persatuan Bangsa- Bangsa (PBB) pada tahun 1945. Tiga puluh tahun kemudian yaitu sekitar pertengahan tahun 1970an, muncul globalisasi ke dua yaitu globalisasi ekonomi yang ditandai dengan lahirnya perdagangan bebas dan terbentuknya kerjasama ekonomi internasional dan regional seperti APEC dan AFTA. Kemudian tiga puluh tahun berikutnya lagi, sekitar pertengahan tahun 2000an, lahir globalisasi ke tiga, yaitu globalisasi budaya. Ciri-ciri globalisasi budaya adalah bangsa-bangsa di dunia menuju kepada satu kultur besar untuk di sharing bersama-sama serta semakin memudarnya identitas budaya lokal. Dari kronologis lahirnya globalisasi tersebut, jika tren tersebut dipertahankan dan konsisten, maka dapat diprediksi bahwa setiap 30 tahun akan muncul 
era baru globalisasi. Oleh karena itu, pada pertengahan tahun 1930an diprediksi akan lahir sebuah era baru globalisasi, dan jika melihat fenomena yang ada diperkirakan kemungkinan besar adalah globalisasi pendidikan.

\section{Embrio Globalisasi Pendidikan}

Banyak fakta yang dapat dijadikan indikator akan lahirnya globalisasi pendidikan. Salah satu embrio akan lahirnya globalisasi pendidikan adalah tren mahasiswa asing yang terus menerus meningkat secara merata di dunia. Dewasa ini jutaan mahasiswa lintas negara menimba ilmu pengetahuan di berbagai perguruan tinggi di berbagai negara dengan status overseas student (mahasiswa asing). Data dari Department of Education and Training, Australia, menunjukkan bahwa jumlah mahasiswa asing yang sedang belajar di perguruan tinggi di Australia sangat tinggi. Pada tahun 2014, perguruan tinggi di Australia menampung 328.659 mahasiswa asing dari berbagai negara. Jumlah tersebut terdiri dari $25 \%$ dari total mahasiswa yang sedang belajar di perguruan tinggi di Australia. Dari total mahasiswa asing tersebut di atas 17.000 mahasiswa berasal dari Indonesia. Walaupun tidak sebanding dengan jumlah mahasiswa Australia yang belajar di Indoneia yang jumlahnya hanya sekitar 50 orang, data tersebut menunjukkan bahwa dunia ini sedang memasuki era baru globalisasi, yaitu globalisasi pendidikan.

Sejalan dengan peningkatan jumlah mahasiswa internasional di Australia, jumlah mahasiswa asing di Jerman juga terus meningkat. Menteri Pendidikan Jerman, Johanna Wanka, menyatakan bahwa pada tahun 2014 mahasiswa asing yang sedang belajar di Jerman jumlahnya mencapai mencapai 300.000. mahasiswa. Jumlah ini mengambil porsi $21,4 \%$ dari total mahasiswa yang ada. Porsi ini menunjukan peningkatan dibanding tahun sebelumnya, seperti yang dilaporkan oleh kantor Statistik Federal Jerman bahwa terjadi peningkatan sebesar 4,5\%. Dengan demikian, ada indikasi bahwa derap maju jumlah mahasiswa asing di Jerman terus meningkat secara berkesinambungan. Mahasiswa dari Indonesia juga jumlahnya meningkat setiap tahun. Dalam lima tahun terakhir, minat mahasiswa Indonesia kuliah di Jerman naik secara signifikan. Pada tahun 2013 lalu, tercatat ada 4.000 pelajar Indonesia kuliah di negeri tersebut. Capaian itu menunjukkan peningkatan 100 persen lebih dibandingkan periode sebelumnya yang tercatat sekitar 1.500 mahasiswa. Disamping mahasiswa, ada sekitar 25.000 ilmuwan asing yang bekerja pada perguruan tinggi di Jerman. Sukses yang dicapai dalam internasionalisasi dunia ilmu di Jerman didasarkan atas upaya bersama dari universitas-universitas dan lembaga penelitian disana. Fenomena ini tidak diragukan lagi untuk mendorong lahirnya globalisasi pendidikan.

Di Amerika Serikat, jumlah mahasiswa internasional juga meningkat dari tahun ke tahun. Pada tahun 2012 mahasiswa asing yang kuliah di perguruan tinggi di Amerika serikat angkanya mencapai lebih dari 764.000. Angka tersebut merupakan peningkatan sebesar hampir enam persen dibanding angka setahun sebelumnya, dan pada tahun 2014 jumlah mahasiswa asing yang belajar di perguruan tinggi di Amerika Serikat sudah 
mencapai 886.000 mahasiswa. Duta Besar Amerika untuk Indonesia, Robert Orris Blake, dalam Kuliah Umum bertajuk "The Future of Our Bilateral Relationship" yang diselenggarakan Kajian Wilayah Amerika di Auditorium UI, Depok, Rabu 19 November 2014 mengatakan bahwa mahasiswa asing di Amerika Serikat kebanyakan berasal dari tiga negara Asia yaitu Tiongkok, India dan Korea Selatan. Total mahasiswa internasional dari tiga Negara ini hampir separuh dari jumlah mahasiswa asing yang belajar di AS.

Pada tahun 2014 tercatat 194.000 (22\%) mahasiswa asing di perguruan tinggi di Amerika berasal dari Tiongkok. Mahasiswa asal Tiongkok kebanyakan kuliah program S-1. Banyak keluarga Tiongkok yang mampu membayar pendidikan berkualitas tinggi bagi anak-anak mereka, dan mereka umumnya memilih untuk belajar di Amerika Serikat. Setelah Tiongkok, India mengirimkan mahasiswa kedua terbanyak untuk mengenyam pendidikan tinggi di Amerika yang jumlahnya sekitar 100.000 (12\%) mahasiswa. Sedangkan Korea Selatan adalah negara ketiga dengan jumlah sekitar 72.000 (8\%) mahasiswa. Dubes Amerika Serikat untuk Indonesia dalam kesempatan yang berbeda di Ruang Multimedia gedung pusat UGM 26 Maret 2014 mengatakan bahwa jumlah mahasiswa Indonesia yang sedang belajar di Amerika Serikat sekitar $8.000(0.9 \%)$ mahasiswa. Sementara itu, institusi AS yang paling populer di kalangan mahasiswa asing adalah Harvard University, Columbia University, New York University, University of California, Berkeley University dan Yale University.

Jepang sebagai negara di benua Asia yang termaju juga menampung banyak mahasiswa internasional. Mahasiswa asing dari seluruh penjuru dunia terus menerus berdatangan ke Jepang untuk menimba ilmu pengetahuan dan jumlahnya terus menerus meningkat dari tahun ke tahun, dan pada tahun 2012 jumlah mahasiswa internasional di jepang mencapai angka 137.756 mahasiswa. Dari total jumlah tersebut, ada 2276 mahasiswa dari Indonesia dan jumlahnya meningkat menjadi 2410 mahasiswa pada tahun 2013. Angka tersebut berada pada posisi ke 6 dalam hal jumlah mahasiswa asing terbanyak di Jepang.

Selain tingginya arus mahasiswa belajar ke luar negeri sebagai embrio lahirnya globalisasi pendidikan sebagaimana diungkapkan di atas, di Indonesia, ada beberapa fakta yang dapat diadikan sebagai alasan akan lahirnya globalisasi pendidikan. Perguruan tinggi terdepan di tanah air seperti Universitas Gajah Mada (UGM), Universitas Indonesia (UI), Institut Teknologi Bandung (ITB) telah menjalin hubungan kerja sama dengan beberapa perguruan tinggi di negara maju dalam membangun kelas internasional. Double degree program adalah fakta yang jelas bahwa globalisasi pendidikan itu sudah mulai sedikit demi sedikit terbangun. Perguruan tinggi tersebut di atas, sebagai contoh, telah lama memiliki kelas international pada program S1. Kelas internasional tersebut telah menggunakan bahasa internasional sebagai bahasa pengantar kuliah, dan beberapa semester para mahasiswa mengambil beberapa mata kuliah di perguruan tinggi mitra di luar negeri, seperti Amerika Serikat, Jerman, Prancis, 
Nedherland, Australia, Jepang, dan lain-lain. Para mahasiswa Double Degree program ini mendapatkan dua ijazah, satu dari perguruan tinggi asal di tanah air dan satu dari perguruan tinggi mitra di lar negeri.

Fakta lain sebagai embrio globalisasi pendidikan adalah lahirnya Rintisan Sekolah Bertaraf Internasional (RSBI) dan Sekolah Bertaraf Internasional (SBI). Terlepas dari pro-kontra program tersebut, upaya membangun sekolah bertaraf internasional di tanah air merupakan upaya pemerintah mempersiapkan anak bangsa dalam menghadapi pengaruh globalisasi khususnya dalam bidang pendidikan. Selain itu, program ini bertujuan untuk menyetarakan dan memajukan pendidikan yang ada di Indonesia, setidaknya lembaga - lembaga mulai dari SD/MI, SMP/M.Ts, dan SMA/SMK/MA bisa dilirik dan dijadikan sebagai pilihan bagi masyarakat yang berdomisili di luar negeri atau dari luar Negara Indonesia. Tentunya untuk mendapatkan standart sekolah bertaraf internasional tersebut tidak dengan mudah, akan tetapi diperlukan banyak syarat yang harus dipenuhi dari suatu lembaga guna mendapatkan predikat internasional dari kementerian pendidikan.

Untuk menjadi sekolah bertaraf internasional, sebuah sekolah harus memenuhi beberapa persyaratan. Sekolah tersebut harus mendapatkan predikat sekolah standar nasional (SSN). Pada taraf ini, sekolah tersebut diberikan fasilitas yang memenuhi standar internasional, mulai menggunakan bahasa internasional dalam proses belajar mengajar, dan masih banyak syarat lainnya yang harus dipenuhi. Apabila sekolah tersebut sudah memenuhi kriteria yang ditentukan oleh kementerian pendidikan, maka sekolah tersebut berhak menyandang gelar Rintisan Sekolah Bertaraf Internasional (RSBI). Selama lima tahun sekolah itu akan mendapat binaan dari pemerintah, mulai dari perlengkapan fasilitas, pendanaan operasional, kurikulum yang diterapkan dan beberapa aspek lain. Setelah lima tahun didampingi oleh pemerintah, dalam hal ini kementerian Pendidikan Nasional, maka sekolah tersebut harus mandiri untuk melaksanakan program tersebut. Jika sudah mampu mandiri, maka statusnya bukan lagi sebagai rintisan sekolah internasional melainkan sekolah yang bertaraf internasional. Dengan meraih predikat sebagai sekolah bertaraf internasional maka materi kurikulum pada sekolah tersebut harus mengacu dan sesuai dengan materi yang ada di dunia pendidikan internasional. Tentu dengan program ini pemerintah berharap agar sekolahsekolah yang mendapatkan predikat internasional bisa bersaing tidak hanya dalam konteks dalam negeri tapi juga luar negeri. Para lulusan sekolah bertaraf internasional diharapkan bisa membawa bangsa Indonesia berbicara di kancah internsional melalui dunia pendidikan dan menjawab tantangan globalisasi pendidikan.

\section{E. Globalisasi Pendidikan: Tantangan dan Harapan}

Fakta menunjukkan bahwa perguruan tinggi yang berkualitas tinggi telah menjadi incaran bagi para lulusan Sekolah lanjutan atas. Berkualitas dapat diterjemahkan menjadi unggul dalam sistem proses belajar mengajar, up to date dengan teknologi informasi, dan mampu menghasilkan lulusan yang handal. Kata "Globalisasi" sering 
disebut-sebut sebagai pemicu bagi perguruan tinggi dalam mempromosikan institusinya kepada masyarakat. Faktanya, banyak slogan terpampang dimana-mana dengan menggunakan kata "globalisasi" menghiasi pamflet, iklan, brosur dan sebagainya.

Globalisasi dapat dipandang sebagai kesempatan untuk maju dan menjadi unggul dalam menghadapi persaingan global. Namun pihak lain mengasumsikan globalisasi sebagai hal yang menakutkan dan sifatnya destruktif. Pada dasarnya, Globalisasi merupakan kesatuan global semua aspek kehidupan tanpa ada batasan teritorial dimana dimungkinkan terjadinya pertukaran, perdagangan, penyebaran sumber daya, seperti modal, manusia, ilmu pengetahuan, dan teknologi. Penekanan dalam globalisasi terletak pada integrasi secara global dari semua negara melalui proses perdagangan bebas, pergerakan modal, migrasi sumber daya manusia, modal, dan iptek tanpa dapat dikendalikan dan dicegah oleh aturan dalam suatu negara tertentu. Oleh karena itu globalisasi sering dikatakan sebagai fenomena yang suka atau tidak suka, mau atau tidak mau, siap atau tidak siap akan dihadapi setiap negara dalam era globalisasi. Kompetisi dalam era globalisasi didasarkan pada keunggulan absolut yang tidak dapat dikendalikan atau diatur oleh pihak manapun.

Bentuk kongret dari pengaruh globalisasi dalam kehidupan perguruan tinggi di Indonesia telah dirasakan sejak satu dekade terakhir dimana negara maju dapat dengan bebas masuk dan mendirikan perguruan tinggi di Indonesia. Kurikulum dan proses belajar mengajar pun diadopsi dari negara asal tanpa harus mengikuti aturan dari Departemen Pendidikan Nasional begitu juga dengan dosen yang didatangkan dari luar. Seiring dengan itu, banyak juga perguruan tinggi di Indonesia yang telah menerapkan strategi mempertahankan mutu agar tetap bertahan di masyarakat. Strategi yang diterapkan diantaranya dalam bentuk kegiatan pertukaran dosen dan mahasiswa, joint program studi dengan menawarkan kuliah di luar negeri untuk semester tertentu, program dual degree, joint research untuk bidang tertentu dan sebagainya. Strategi ini dilakukan sebagai antisipasi untuk dapat bertahan dengan perguruan tinggi asing yang masuk di Indonesia.

Terlepas dari pro dan kontra mengenai globalisasi di perguruan tinggi, dari perspektif yang positif setidaknya ada beberapa benefit yang bisa diperoleh antara lain masyarakat diperhadapkan dengan banyaknya pilihan perguruan tinggi yang berkualitas dengan standar internasional. Selain itu, negara diuntungkan karena para mahasiswa dapat menghemat biaya dengan tetap kuliah dalam negeri pada lembaga pendidikan asing yang mungkin lebih kopetitif. Selain itu, proses belajar dan mengajar dalam menyebarkan ilmu pengetahun dan teknologi menjadi semakin mudah dan disampaikan dengan lebih elegan. Internet bukan sesuatu yang mewah lagi bagi sebuah perguruan tinggi.

Hal yang menarik dibahas dalam konteks globalisasi di perguruan tinggi adalah peranan teknologi informasi. Poin ini telah menjadi fokus perhatian semua stakeholder di dalam perguruan tinggi. Tidak berlebihan kalo dikatakan bahwa peranan teknologi 
informasi sangat vital bagi perguruan tinggi. Penerapan teknologi informasi yang tepat di perguruan tinggi dapat menjadi competitive advantage bagi perguruan tinggi untuk dapat bertahan. Trend yang berkembang saat ini adalah adanya kecendrungan calon mahasiswa memilih perguruan tinggi yang tidak hanya memiliki gedung yang megah tetapi dilengkapi juga dengan fasilitas e-learning, wireless, Internet, perpustakan digital, dan fasilitas teknologi lainnya. Hampir dapat dipastikan bahwa perguruan tinggi yang tidak mempunyai sentuhan teknologi informasi secara perlahan akan ditinggalkan olah calon mahasiswa.

Terlepas dari dampak positif globalisasi pendidikan, ada beberapa hal yang menjadi tantangan besar bagi perguruan tinggi di tanah air dalam kaitannya dengan globalisasi tersebut. Perlu digarisbawahi bahwa dengan globalisasi, maka dunia pendidikan di tanah air bisa dikuasai oleh para pemilik modal. Negara-negara asing dengan modal yang lebih kuat akan dapat mendirikan perguruan tinggi di tanah air dan menjadi pilihan bagi kalangan tertentu di negara kita. Praktek ini akan melahirkan golongan-golongan didalam dunia pendidikan dan semakin terkikisnya kebudayaan lokal akibat masuknya budaya dari luar. Dampak lain dari globalisasi terhadap perguruan tinggi di tanah air adalah semakin tergantungnya lembaga pendidikan tinggi kita pada teknologi yang bisa mengakibatkan munculnya "tradisi serba instant" serta melonggarnya kekuatan kontrol pendidikan oleh negara.

Globalisasi akan membuka babak persaingan bebas diantara perguruan tinggi secara global. Maka dalam konteks ini perguruan tinggi di tanah air yang beroperasi dibawa standar mutu akan tersingkirkan secara alami. Fakta menunjukkan bahwa tidak sedikit perguruan tinggi yang sedang menanjak lalu koleps seketika. Sebaliknya, tidak sedikit pula perguruan tinggi yang terus menerus mempertahankan kecenderungan kinerja yang meningkat. Fenomena ini erat kaitannya dengan pengaruh globalisasi.

Kesuksesan sebuah perguruan tinggi dalam menghadapi tantangan di dimasa mendatang sangat tergantung pada bentuk manajemen yang diterapkan. Manajemen yang efektif akan mampu membawa sebuah organisasi tampil gemilang di era globalisasi ini. Sebaliknya, manajemen yang kurang efektif akan membawa sebuah organisasi tak berdaya dalam menghadapi persaingan global. Dengan demikian, perlu dipahami lebih mendalam konsep dasar dan prinsip-prinsip manajemen, demikian pula cara mengimplementasikannya secara tepat dalam sebuah perguruan tinggi. Faktor penting lainnya adalah apa yang dapat dipelajari oleh para pimpinan perguruan tinggi dari pengalaman mereka sendiri dalam memimpin organisasi untuk meningkatkan efektifitas dan efisiensi kerja dalam menghadapi tantangan global yang penuh dengan kompetisi dan selalu membawa perubahan drastis yang berakibat pada ketidakpastian.

Dalam menghadapi tantangan globalisasi para pimpinan perguruan tinggi perlu sebuah pendekatan baru dalam kepemimpinan, terutama pada sektor human relation. Alasannya, semakin ketat kompetisi antar organisasi, semakin besar pula ketergantungan organisasi itu terhadap kontribusi para anggota staf. Oleh karena itu 
anggota staf idealnya lebih merupakan mitra dari pada bawahan. Hal ini bisa terwujud jika pimpinan memposisikan diri lebih pada pimpinan tim dan fasilitator dari pada sebagai pemimpin yang instruktif yang tentunya lebih menekankan relasi vertikal dari pada hubungan secara horiontal dengan para anggota staf lain dalam organisasi yang dipimpin. Perguruan tinggi di negara-negara maju yang sadar dengan ancaman globalisasi telah mengalokasikan dana yang cukup besar untuk meningkatkan kualitas para dosen dan pegawai dan melakukan perekrutan calon pegawai yang berkualitas tinggi. Hal ini dilakukan karena perguruan tinggi tersebut yakin bahwa lembaga mereka hanya akan dapat bertahan jika dikelolah oleh staf yang memiliki SDM yang handal.

Perlu ditegaskan bahwa SDM merupakan faktor kunci dalam melakoni persaingan di era global yang sangat ketat. Pada konteks nasional, dewasa ini bangsa Indonesia sibuk melakukan reformasi di bidang ekonomi, politik dan hukum meskipun tak kunjung sampai pada substansinya. Dalam proses reformasi yang sedang berjalan ada gejala ke arah dilupakannya upaya peningkatan SDM bangsa. Hal ini pasti berbahaya dan akibatnya akan dipikul oleh seluruh komponen bangsa Indonesia berupa keterbelakangan dan ketergantungan. Tanpa pengembangan SDM yang memadai bangsa ini akan terpinggirkan dalam persaingan global dan terus menerus menjadi negara konsumen, bukan negara produsen.

Diakui bahwa membangun SDM tidak akan pernah selesai dan tuntas, sepanjang peradaban manusia itu masih ada. Karena jika suatu bangsa selesai menangani satu masalah, akan tumbuh lagi masalah baru dalam peradaban itu. Hal ini terjadi karena tuntutan jaman selalu berubah, seperti yang pernah digambarkan oleh John F Kennedy (mantan Presiden Amerika Serikat) dalam sebuah metafora: Change is a way of life. Those who look only to the past or present will miss the future. Dengan demikian, dalam proses membangun SDM di era globalisasi tidak dapat hanya sekadar mempersiapkan manusia untuk mampu bersaing dalam masyarakat kini, tetapi juga disiapkan berkompetisi dalam masyarakat yang akan datang yang semakin sulit diprediksi karakteristiknya. Dengan cara ini, perguruan tinggi di tanah air tidak akan mendapati globalisasi sebagai momok yang menakutkan.

Sulitnya memprediksi karakteristik masyarakat pada masa yang akan datang disebabkan oleh kenyataan bahwa di era global perkembangan masyarakat tidak linier lagi dan penuh dengan diskontinuitas. Rowan Gibson menggambarkan kondisi ini dengan pernyataannya: The fact is that the future will not be a continuation of the past. It will be a series of discontinuities. Oleh karena itu, keberhasilan yang diraih sebuah organisasi di masa lampau belum tentu memiliki validitas untuk menyelesaikan persoalan masa kini dan masa yang akan datang. Dalam kondisi seperti ini perlu direnungkan ungkapan Rowan Gibson bagi setiap organisasi agar dapat membangun masa depan secara bersama.

Dalam kehidupan global ternyata batas-batas negara secara fisik-geografik menjadi tidak penting lagi. Justru faktor yang penting bagi eksistensi suatu organisasi 
adalah penguasaan teknologi informasi. Dengan adanya berbagai penemuan dalam bidang teknologi informasi, kekuasaan suatu negara dalam arti teritorial menjadi semakin kabur bahkan cenderung mengarah kepada terbentuknya dunia tanpa batas. Di sisi lain dengan teknologi informasi, kita dapat mengelola sebuah organisasi dalam suatu proses yang bersifat virtual. Dengan demikian setiap organisasi harus mampu mempersiapkan anggota stafnya menjadi komunitas yang terberdayakan dalam menghadapi kehidupan global yang semakin lama semakin menggantungkan diri pada teknologi informasi.

\section{PENUTUP}

Setiap perguruan tinggi diharapkan memiliki peran yang signifikan dalam konteks interdependensi terutama dalam skala regional dan global. Untuk meraihnya, sistem pengembangan SDM harus mampu memberdayakan anggota organisasi secara luas. Salah satu ciri anngota staf yang terberdayakan oleh sistem pengembangan SDM organisasinya ialah ketika dimilikinya unggulan komparatif dan unggulan kompetitif dalam konteks yang lebih luas, yaitu regional dan global. Konsekuensinya, pengembangan SDM suatu organisasi harus dikonseptualisasikan sebagai suatu usaha dan proses pemberdayaan, yang benar-benar dan harus disadari secara kolektif dalam rangka melakukan investasi masa depan perguruan tinggi.

Pada era globalisasi seperti saat ini dan juga di masa yang akan datang, penguasaan teknologi informasi menjadi sangat penting bagi eksistensi dan perubahan perguruan tinggi di tanah air. Dilihat dari aspek relevansi, era globalisasi akan berdampak pada cepat usangnya hardware dan software pada berbagai bidang, termasuk bidang manajemen. Dengan demikian sektor pengembangan SDM harus direvisi setiap saat. Untuk melakukan hal ini, dituntut adanya kemauan dan niat yang kuat dari seluruh anggota staf pada semua level organisasi untuk menjaga tingkat unggulan kompetitif yang tinggi dalam berbagai bidang. Untuk menghasilkan unggulan kompetitif, maka inovasi dalam hal pengembangan SDM harus menjadi prioritas penting dalam organisasi. Tanpa inovasi yang signifikan, sebuah perguruan tinggi hanya akan memiliki anggota staf yang tidak mandiri, selalu tergantung pada pihak lain. Dalam perspektif global, anggota staf seperti itu hanya akan menjadi beban bagi perguruan tingginya. 


\section{DAFTAR PUSTAKA}

Alexander, FK., "The Changing Face of Accountability: Monitoring and Assessing Institutional Performance", Journal of Higher Education, Vol. 71, No. 4, 2005, pp. 441-431.

Bill Guerin, "Indonesia behind the learning curve", Asia Times - August 30, 2006, pp. 69.

Brodjonegoro, SS., Higher Education in Developing Countries: Peril and Promise, http://www.tfh.net/resources/satryo_soemantri_brodjonegoro2.htm, 13-09-2006, 04.pm.

Chipman, L., "Globalisation and the Higher Education Providers of the 21st Century", Paper presented to the Australian Association for Institutional Research 12th Annual Conference, Queensland, 3-5 September 2003.

Dubrin, A J., Leadership: The Complete IDEAL'S GUIDES, Jakarta, Prenada, 2000.

Fadhil, K., Kompas edisi 14, November 2004.

Gale, T., and McNamee, P., Just Out of Reach: Access to Equity in Higher Education, Australian Universities Review, Vol. 37, No. 2, 2002, pp. 8-12.

Guerin, B., "Indonesia behind the learning curve", Asia Times - August 30, 2006, pp. 69.

Hassan, R., "Islamic Thought in Limbo", The Australian, $19^{\text {th }}$ Edition, December 2006, pp. 3-4.

Indrajit, RE.; Djokopranoto, R., Manajemen Perguruan Tinggi Modern, Yogyakarta, ANDI, 2006.

Jalal, F.; dan Musthafa B., (eds.), Education Reform in the Context of Regional Autonomy: the Case of Indonesia, Jakarta, Ministry of National Education, 2003.

Lihat Kompas edisi 14, November 2004.

Michael, S., "Higher Education Institutional Collaborations", Journal of Higher Education Policy and Management, Vol. 25, No. 2, November 2003, pp. 130-146.

Riaz Hassan, "Islamic Thought in Limbo", The Australian, 19 ${ }^{\text {th }}$ Edition, December 2006, p. 3-4.

Satryo Soemantri B, Higher Education in Developing Countries: Peril and Promise, http://www.tfh.net/resources/satryo_soemantri_brodjonegoro2.htm, 13-09-2006, 04. pm., pp. 1-10. 
Scholte, Jan Aart (2001) "The Globalization of World Politics," in Baylis, John \& Smith, Steve (eds.), The Globalization of World Politics, $2^{\text {nd }}$ edition, Oxford University Press, pp. 13-34.

See Globe Asia, 2008, pp. 13-15.

See Globe Asia, p. 14, and journal of Higher Education Policy and Management, Vol. 25, No. 2, November 2003, pp. 161-172.

See "Pelita Harapan University: Global Campus for Indonesia, 2008, pp. 18-23.

See "University of Indonesia, Indonesia's Top University: Truly comprehensive; strong in research; exerts wide influence, Globe Asia, 2008. pp. 24-27.

See "The Best Investment Money can Buy", Globe Asia: Top Guide to 10+10 Indonesian Universities, $1^{\text {st }}$ Annual Issue, 2008, p. 14.

Sinclair, M., "Three Futures for University Provision: The Social Justice Market, State Capitalism, and Private for-Profit University", Journal of Higher Education Policy and Management, Vol. 25, No. 2, November 2003, pp. 161-172.

Smith, Steve \& Baylis, John (2001) "Introduction," in Baylis, John \& Smith, Steve (eds.), The Globalization of World Politics, $2^{\text {nd }}$ edition, Oxford University Press, pp. 1-12.

Tilaar, HAR., Manajemen Pendidikan Nasional: Kajian Pendidikan Masa Depan, Bandung, Rosdakarya, 2006.

Tjiptono, F., Diana, A., Total Quality Management, Yogyakarta, ANDI, 2003

Turney, C; Hatton, N., The School Manager: Educational Management Roles and Tasks, Sydney, ALLEN \& UNWIN, 2001.

UNDP., "Towards a New Consensus: Democracy and Human Development in Indonesia", Indonesia Human Development Report 2005, October 2005, pp. 132156.

Zainuddin, SK., "The Best Investment Money can Buy", Globe Asia: Top Guide to 10+10 Indonesian Universities, $1^{\text {st }}$ Annual Issue, 2008. pp. 13-17. 